\title{
Behavior of tamarins, tanagers and manakins foraging in a strangler fig (Ficus sp.) in Suriname, South America: implications for seed dispersal
}

\author{
Elizabeth Natasha Vanderhoff $f^{1,3,4}$ \& Brian Grafton ${ }^{2}$ \\ ${ }^{1}$ Francis Marion University, Florence, SC 29502 \\ ${ }^{2}$ Kent State University, Kent, $\mathrm{OH} 44242$ \\ ${ }^{3}$ Jacksonville University, 2800 University Blvd. N., Jacksonville, FL 32211 \\ ${ }^{4}$ Corresponding author: Elizabeth Natasha Vanderhoff, nvander4@ju.edu
}

VANDERHOFF, E.N. \& GRAFTON, B. Behavior of tamarins, tanagers and manakins foraging in a strangler fig (Ficus sp.) in Suriname, South America: implications for seed dispersal. Biota Neotrop. 9(3): http://www. biotaneotropica.org.br/v9n3/en/abstract?short-communication+bn03809032009.

\begin{abstract}
The behavior of foragers can directly affect the dispersal of seeds. Strangler figs are keystone resources throughout the tropics and are important resources for both primates and birds. We examined the foraging behavior of golden-handed tamarins and four bird species in a strangler fig to see how these behaviors might affect the dispersal of fig seeds. Tamarins removed fruit at a faster rate than did any of the bird species examined. Additionally, tamarins tended to swallow figs whole whereas birds tended to drop figs once they were processed. Tamarins visiting fig trees ingest large quantities of fig seeds that may be deposited throughout the forest. Birds on the other hand tended to slowly process fruits near the fig tree and drop processed fruit containing large quantities of seeds. Future studies need to be conducted to ascertain differences in post dispersal seed fate.
\end{abstract}

Keywords: frugivores, feeding rate, manakins, quality of seed dispersal, tamarins, tanagers.

VANDERHOFF, E.N. \& GRAFTON, B. Comportamiento de los tamarins, de los tanagers y de los manakins forrajeando en un higo del estrangulador (Ficus sp.) en Suriname, Suramérica: implicaciones para la dispersión de semilla. Biota Neotrop. 9(3): http://www.biotaneotropica.org.br/v9n3/es/abstract?shortcommunication+bn03809032009.

Resumen: El comportamiento de foragers puede afectar directamente la dispersión de semillas. Los higos del estrangulador son recursos trapezoidales a través de las zonas tropicales y son recursos importantes para los primates y los pájaros. Examinamos el comportamiento del forraje de tamarins de oro-dados y cuatro especies del pájaro en un higo del estrangulador para ver cómo estos comportamientos pudieron afectar la dispersión de las semillas del higo. Fruta quitada Tamarins en una tarifa más rápida que la especie ua de los del pájaro examinada. Además, los tamarins tendieron para tragar los higos enteros mientras que los pájaros tendieron para caer los higos que fueron procesados una vez. Los árboles de higo de Tamarins que visitan injieren cantidades grandes de semillas del higo que se puedan depositar a través del bosque. Los pájaros por otra parte tendieron para procesar lentamente las frutas cerca del árbol de higo y la gota procesó la fruta que contenía cantidades grandes de semillas. Los estudios futuros necesitan ser conducidos para comprobar diferencias en sino de la semilla de la dispersión del poste.

Palabras-clave: frugivores, nivel de entrada, manakins, calidad de la dispersión de la semilla, tamarins, tanagers. 


\section{Introduction}

Figs (Ficus spp. Moraceae) play a vital role in tropical communities; they are keystone resources and the most important fruit resource for frugivores in the tropics, providing nutrition in times of scarcity (Shanahan et al. 2001; Terborgh 1986). Numerous vertebrates visit fruiting figs and a single tree often contains a diverse foraging assemblage (Coates-Estrada \& Estrada 1986; Goodman et al. 1997). Primates and birds are strongly attracted to figs (Breitwisch 1983). For example, approximately half of the diet of the Peruvian spider monkey (Ateles chamek) is composed of figs (Felton et al. 2008) and the Mexican howler monkey (Alouatta palliata mexicana) spends $64 \%$ of the foraging time feeding on figs (Serio-Silva et al. 2002). Figs are similarly a critical resource for numerous bird species (Lambert \& Marshall 1991), and avian species richness can be associated with fig species richness (Kissling et al. 2007). Additionally, both primates and birds are important dispersers of fig seeds, and ingestion often aids germination (Compton et al. 1996; De Figueiredo 1993; Goodman et al. 1997; Knogge et al. 2003; Lambert \& Marshall 1991). However, in order for many fig seeds to germinate they need to be dispersed to favorable microsites. This is most notable in strangler figs whose seeds must be deposited within the canopy in areas of high light and adequate moisture (Laman 1995).

The behavior of dispersers can have a large effect on when, where, and how seeds are dispersed (Chapman \& Russo 2006; Westcott et al. 2005). For example, the Three-wattled Bellbird (Procnias tricarunculata) disperses seeds under song perches in forest openings; thus the bellbirds' courtship behavior affects where seeds are dispersed (Wenny \& Levey 1998). Foraging behavior within fruiting trees is an important component of the seed dispersal process and includes visitation rates, fruit choice, handling and removal (Wang \& Smith 2002). While these behaviors can affect the quantity of fruits removed, the quality of seed dispersal is dependent on internal fruit processing within the animal and seed deposition (Schupp 1993). Knowledge of animal foraging behavior within individual fig trees can lead to a better understanding of the relative importance of various frugivores as effective seed dispersers and their individual contributions to seed shadows.

Primates and birds have disparate foraging patterns and the contribution of each to the dispersal of fig seeds is likely to differ. Given the importance of figs in tropical communities and the importance of foraging behavior for the dispersal of fig seeds, we examined the foraging behavior of primates and birds foraging in a strangler fig. We wanted to describe foraging behavior both qualitatively and quantitatively and to ascertain how the behavior of primates and birds within a single fig tree might ultimately affect seed dispersal.

\section{Materials and Methods}

We conducted our investigation on the plateau at Brownsberg Natuur Park (hereafter referred to as Brownsberg) in Suriname $\left(5^{\circ} 01^{\prime} \mathrm{N}\right.$ and $\left.55^{\circ} 34^{\prime} \mathrm{W}\right)$. Brownsberg is a 12,200 ha wildlife park consisting of a lateritic plateau $(473 \mathrm{~m})$ surrounded by steep slopes and covered by tall primary and secondary forest (De Dijn et al. 2007; Norconk et al. 2003). Temperatures are mild on the plateau $\left(19^{\circ}\right.$ to $30^{\circ} \mathrm{C}$ ) and annual rainfall averages about $155 \mathrm{~cm}$ (De Dijn et al. 2007). Eight primate species are found in Suriname and occur at Brownsberg; however, the golden-handed tamarin (Saguinus midas Linnaeus, 1758) and the red howler monkey (Alouatta seniculus Linnaeus, 1766) are the most abundant primates on the plateau (Norconk et al. 2003). Brownsberg also supports 387 species of birds, including 30 species that are endemic to the Guyana Shield (De Dijn et al. 2007).
We observed one strangler fig (Ficus sp.) that was approximately $12 \mathrm{~m}$ tall with a crown that was $12 \mathrm{~m}$ in diameter. The fig was located alongside a park road making observations of foraging behavior ideal; the majority of the tree crown and fruits were visible from the road. Fruits were small $(1.18 \pm 0.04 \mathrm{~cm})$ and aggregated in clusters on terminal branches. Fruits were abundant throughout the study (crop size $>1,000)$ and the majority of the fruits $(>75 \%)$ were unripe and green in color; ripe fruit was reddish-purple in color.

Our observations were made during the rainy season from July 17 through July 25, 2008, at the beginning of a period of fruit scarcity for the site (De Dijn et al. 2007). Observations were made between approximately 06:30 AM and 05:00 PM. Over the nine days, we recorded which primates and birds foraged in the tree. We calculated the total visits per species and the average number of visits per day. For the following analyses we included only species that visited tree or more than one day; therefore we only included tamarins and four bird species. In order to understand how primate and bird visitation affected fruit removal we calculated foraging bout length for tamarins and birds, as well as fruit foraging rates. A foraging bout for tamarins began when the first tamarin in a group entered a tree and ended when the last tamarin left the tree. Because birds often fly from a fruiting tree to a nearby perch, we did not use the same method for birds. We instead defined a foraging bout as the time from when a bird first entered a tree until the bird left the foraging tree for at least five minutes. Thus, if a given bird picked a fruit, ate it, and returned to the tree within five minutes, all this activity was included in a single bout. We used an ANOVA to ascertain if the length of foraging bouts differed among bird species and we used a T-test to compare foraging times between monkeys and birds.

We also conducted continuous focal observations and noted when a fruit was picked, if a fruit was dropped once processed, and whether or not the fruit was ripe. We noted whether or not fruits were dropped after being processed because dropped fruits contained numerous seeds. For tamarins, observations began as soon as a tamarin was visible in the tree until it was out of view or left the tree. If another tamarin was in the tree a scan would begin on that tamarin following the previous scan. Birds often flew in, picked a fruit, ate, and flew to another location within the tree or left the tree. Therefore, to standardize bird foraging rates, we began bird observations when a fruit was picked and ended observations when the bird was finished picking and eating fruits. We compared foraging rates (the amount of fruits picked/minute) for monkeys and birds with an ANOVA. We then compared the proportion of fruits dropped after fruit processing by monkeys and birds with a Chi-square test. Lastly, we compared the proportion of ripe fruit (reddish-purple in color) picked by monkeys and birds using a Chi-square test.

For the four species of birds we examined two additional foraging behaviors. We compared the proportion of birds that caught fruits on the wing to the proportion that captured fruits by hopping through the canopy with a Fisher's Exact test. We also used a Fisher's Exact test to examine the proportion of birds that processed fruit from within the fig tree to those that processed outside the fig. We used SAS for all analyses, and when necessary we used a log transform to normalize data. All t-tests are two-tailed, and we report means \pm SE from untransformed data.

\section{Results}

The golden-handed tamarin and four bird species, the bay-headed tanager Tangara gyrola Linnaeus, 1758 (BHT), golden-sided euphonia Euphonia cayennensis Gmelin, 1789 (GSE), white-fronted manakin Lepidothrix serena Linnaeus, 1766 (WFM), and goldenheaded manakin Pipra erythrocephala Linnaeus, 1758 (GHM), 
Table 1. Summary of foraging behaviors of birds and tamarins in a strangler fig (El resumen de adentrarse conductas de pájaros y tamarins en un higo estrangulador).

\begin{tabular}{lcccccccc}
\hline \multicolumn{1}{c}{ Species } & N & $\begin{array}{c}\text { Days } \\
\text { visited }\end{array}$ & $\begin{array}{c}\text { Ave. number } \\
\text { visits/day }\end{array}$ & $\begin{array}{c}\text { Ave. length of } \\
\text { bout (min) }\end{array}$ & $\begin{array}{c}\text { Foraging } \\
\text { rate }\end{array}$ & $\begin{array}{c}\text { Ripe fruit } \\
\text { consumed }\end{array}$ & $\begin{array}{c}\text { Dropped } \\
\text { fruit }\end{array}$ & $\begin{array}{c}\text { Fruit processed } \\
\text { within tree }\end{array}$ \\
\hline Bay-headed Tanager & 42 & 8 & 3.125 & $12 \pm 2.11$ & $1.67 \pm 0.152$ & $71.40 \%$ & $100 \%$ & $76.20 \%$ \\
Golden-sided Euphonia & 16 & 4 & 0.75 & $21.8 \pm 10.66$ & $1.87 \pm 0.233$ & $81.30 \%$ & $100 \%$ & $81.30 \%$ \\
Golden-headed Manakin & 7 & 4 & 0.75 & $4.6 \pm 1.36$ & $1.55 \pm 0.363$ & $85.70 \%$ & $100 \%$ & $28.60 \%$ \\
White-fronted Manakin & 5 & 2 & 0.375 & $9.66 \pm 4.48$ & $0.87 \pm 0.179$ & $60.00 \%$ & $100 \%$ & $25.00 \%$ \\
Golden-handed Tamarin & 39 & 9 & 3.5 & $6.65 \pm 0.75$ & $6.47 \pm 0.98$ & $26.00 \%$ & $18 \%$ & $100 \%$ \\
\hline
\end{tabular}

$* \mathrm{~N}=$ total number of feeding bouts; and $*$ foraging rate $=$ number of consumed fruits per minute.

were the most frequent foragers in the fig (Table 1). Only one other primate visited the fig; a group of red howlers (Alouatta seniculus) foraged there on one occasion. Several other birds foraged in the tree only once (Trogon Trogon sp., Slate-colored Grosbeak Saltator grossus Linnaeus, 1786, Red-and-Black Grosbeak Periporphyrus erythromelas Gmelin, 1789, Ruddy Pigeon Patagioenas subvinacea Lawrence, 1868, Toucanet Aulacorhynchus sp.), and therefore, like the howler, they were not included in further analyses.

There were no significant differences in foraging bout time for the four bird species (ANOVA: $\mathrm{F}_{4,35}=1.60, \mathrm{p}=0.1952$; Table 1). However, birds spent significantly more time foraging in the fig per bout than did tamarins ( $t$-test: $\left.\mathrm{T}_{49.4}=2.435, \mathrm{p}=0.0185\right)$. Whereas tamarins spent an average of $6.65 \pm 0.75$ minutes per bout, birds averaged $11.85 \pm 2.0$ minutes. Although the tamarins spent less time in the tree per visit, their foraging rates and thus fruit removal was greater than any of the four bird species (ANOVA: $\mathrm{F}_{4,95}=25.43$, $\mathrm{p}<0.0001$; Table 1). This was in large part due to the way in which fruit was processed; whereas tamarins usually ate figs whole, all the birds examined were fruit mashers (Moermond \& Denslow 1983). Mashers squeeze the pulp out of the figs and then drop the fruit, a time-consuming process that limits fruit consumption. As a result of this fruit processing behavior, birds dropped portions of all processed fruits $(100 \%)$, many of which contained seeds, whereas tamarins dropped a smaller proportion of processed fruits, approximately $16 \%$ $\left(\chi^{2}=160.10, \mathrm{p}<0.0001\right)$. Additionally, birds consumed a significantly greater proportion of ripe fruits than did tamarins. Whereas $26 \%$ of the fruits consumed by tamarins were ripe, $74 \%$ of fruit picked and eaten by birds were ripe $\left(\chi^{2}=106.86, \mathrm{p}<0.0001\right.$; Table 1$)$. Among the four bird species there were also significant differences in how fruits were picked (Fisher's Exact test $\mathrm{p}<0.0001$ ) and where fruits were processed (Fisher's Exact test $\mathrm{p}<0.0001$ ). The two Manakins captured a higher proportion of fruit on the wing; The WFM captured $100 \%$ of fruit on the wing and the GHM captured $86 \%$ of fruit on the wing. The BHT and GSE, on the other hand, tended to hop through the tree and pick individual fruits from perches; the BHT only captured $7 \%$ of fruit on the wing and the GSE captured slightly more on the wing $(25 \%)$. The two manakins also tended to process fruits outside of the tree in nearby lianas, whereas the tanagers (BHT and GSE) stayed in the tree to process fruit. The GSE and BHT processed about $75 \%$ (GSE $81 \%$, BHT 76\%) of the fruit they picked in the fig compared to about $25 \%$ for the manakins (WFM 25\%, GHM 28\%).

\section{Discussion}

The specific foraging behaviors of primates and birds have implications for seed dispersal and our results suggest that tamarins consume more seeds and may be important dispersers of this strangler fig (Ficus sp.). Tamarins removed fruit at a faster rate than any of the bird species. Additionally, tamarins swallowed most of the fruits whole, whereas all birds where fruit mashers. This behavioral difference has important consequences for seed dispersal. Fruit mashers tend to deposit seeds under parent trees where the seeds have a lower chance of survival (Janzen 1970; Levey 1987). However, tamarins also deposited some seeds below the tree and not only via fruit dropping. Their fecal materials, especially during the first visits in the morning, contained almost exclusively fig seeds, and in total over 5000 seeds were deposited (Grafton \& Vanderhoff unpublished data). However, given the copious amounts of seeds (approximately 9,000 seeds recovered from tamarin feces) and the fast moving behavior of the tamarins it is likely that seeds were also deposited away from the parent tree. Tamarins are larger ( $~ 500 \mathrm{~g})$ than either tanagers $(\sim 20 \mathrm{~g})$ or manakins $(\sim 12 \mathrm{~g})$ and have longer gut passage times. Tamarins might also deposit seeds in the specific microsites for strangler fig seed germination, branches of trees within the canopy. Our study did not investigate treatment of seeds after ingestion and differences in gut treatment may either enhance or counteract the effects of removing large amounts of seeds from the parent plant. Other investigations have shown that tamarins are important dispersers of figs. For example, fig seeds dispersed by both the moustached tamarin (Saguinus mystax) and the saddle-back tamarin (Saguinus fuscicollis) successfully germinate (Knogge et al. 2003).

In our study there were also significant differences between tamarins and birds in their fruit selection, with tamarins selecting unripe green fruit and birds selecting ripe reddish-purple fruit. Fruit color is often a cue to frugivores indicating fruit ripeness (Wheelwright $\&$ Janson 1985), and a recent study indicates that fig color, as well as size, may have evolved in response to dispersers, with bird-dispersed figs being brightly colored (Lomascolo et al. 2008). Similar to our findings, another investigation also found that birds tend to consume fig fruits that ripen reddish in color (Korine et al. 2000). Fruit dispersed by primates are also often colorful; however, several primates consume green and unripe fruits. For example, the Peruvian spider monkey Ateles chamek while foraging on Ficus boliviana spends $65 \%$ of the time consuming unripe figs (Felton et al. 2008). Red howlers are also known to consume green fruits (Julliot 1996), and we observed howlers consuming green unripe figs at Brownsberg. Although seeds from green figs were passed through the tamarin gut intact, it remains unclear whether or not seeds dispersed at this stage are as viable as seeds from ripe reddish-purple fruit. It may be the case that tamarins, by consuming green unripe fruit, act as seed predators and not dispersers.

Among birds, we found differences between tanagers and manakins. Whereas tanagers tended to pick fruit from perches and process fruit in fig trees, manakins captured figs on the wing and tended to process fruit outside of the fig tree. As far as we could tell agnostic interactions were not responsible for this difference. Tanagers may be suitable dispersers if they consume enough seeds and travel to other trees to forage and deposit seeds on the branches of trees while foraging. On the other hand, manakins may be more 
effective dispersers, as they quickly remove fruit from the vicinity of the parent tree. Manakins may remove fruit to lekking areas, and this additional behavioral difference between tanagers and manakins may have important consequences for dispersal, as male manakins deposit large numbers of seeds in these areas (Krijger et al. 1997; Wenny 2001). However, these sites are often in the understory and may not be suitable for strangler fig germination. Future studies are needed to fully understand the role of tanagers and manakins as dispersers of strangler figs.

Our study was conducted over a relatively short time period and only one strangler fig was observed. Given these facts, it is likely that our study overlooked many important factors and the conclusions we draw are preliminary at best. First, we did not observe foraging behaviors for the entire period of fruit availability within the fig. Further observations may have shown that as more ripe fruits become available, foraging behavior within the tree may change and preferences for unripe over ripe fruit may also change, at least for the tamarins. Moreover, the frugivore assemblage may also change and thus we may have missed important dispersers. Although only one tree was observed, the general foraging tendencies (fruit handling, processing and removal) are likely to be similar for both tamarins and birds foraging for fruits of a similar size and seed make-up and for other strangler figs in the area. The tree that we observed was located along a road and thus animals foraging behaviors may have been subject to edge effects. On one occasion we did observe tamarins leaving the tree as tourist approached and foraging bout length may be reduced in the edge as compared to the forest interior. However, the edge may have enhanced foraging for birds, as fruits were more visible and at least one other study has noted that this factor can increase fruit consumption along an edge as compared to forest interior (Galetti et al. 2003).

Understanding the behavior of vertebrate dispersers is becoming increasingly important given the increasing rates of habitat destruction occurring throughout the tropics (Duncan \& Chapman 2002; Pejchar et al. 2008), and may be even more relevant for keystone resources, like the fig, that provide food for numerous animals during times of scarcity (Isabirye-Basuta \& Lwanga 2008; Tello 2003).

\section{Acknowledgements}

We thank the Surinamese park service, STINASU, for permission to conduct research at Brownsberg. We are grateful for the help provided by Marilyn Norconk and all the researchers at Brownsberg. ENV wishes to thank Perri Eason, Douglas Levey and other anonymous reviewers who made helpful suggestions on the manuscript. Financial support was provided to ENV by Francis Marion University's Professional Development Fund.

\section{References}

BREITWISCH, R. 1983. Frugivores at a fruiting Ficus vine in a southern Cameron tropical wet forest. Biotropica. 15(2):125-128.

CHAPMAN, C.A. \& RUSSO, S.E. 2006. Primate seed dispersal, linking behavioral ecology with forest community structure. In Primates in perspective (C.J. Campell, A.F. Fuentes, K.C. MacKinnon, M. Panger \& S. Bearder, eds.). Oxford University Press, New York, p. 510-525.

COATES-ESTRADA, R. \& ESTRADA, A. 1986. Fruting and frugivores at a strangler fig in the tropical rain forest of Los Tuxtlas, Mexico. J Trop Ecol. 2(4):349-357.

COMPTON, S.G., GRAIG, A.J.F.K. \& WATERS, I.W.R. 1996. Seed dispersal in an African fig tree: birds as high quantity, low quality dispersers? J Biogeogr. 23(4):553-563.

DIJN, B., MOLGO, I.E., NORCONK, M.A., GREGORY, L.T., O'SHEA, B., MARTY, C., LUGER, M., RINGLER, M., CROTHERS, S., NOONAN,
B., FITZGERALD, K., MITRO, S., VREEDZAAM, A. \& SATYAWAN, D. 2007. The biodiversity of the Brownsberg. In A rapid biological assessment of the Lely and Nassau Plateaus, Suriname: with additional information on the Brownsberg Plateau. (L.E. Alonso \& J.H. Mol, eds.). Conservation International, Arlington, p. 135-155. (RAP Bulletin of Biological Assessment, v. 43).

DUNCAN, R.S. \& CHAPMAN, C.A. 2002. Limitations of animal seed dispersal for enhancing forest succession o degraded lands. In Seed dispersal and frugivory: ecology, evolution and conservation (D.J. Levey, Silva, W.R. \& Galetti, M., eds.). CABI International Publishing, Oxford, p. 437-450.

FIGUEIREDO, A.R. 1993. Ingestion of Ficus enormis seeds by howler monkeys (Alouatta fusca) in Brazil: effects on seed germination. J Trop Ecol. 9(4):541-543.

FELTON, A.M., FELTON, A., WOOD, J.T. \& LINDENMAYER, D.B. 2008. Diet and feeding ecology of Ateles chamek in a Bolivian semihumid forest: the importance of Ficus as a staple food resource. Int J Primatol. 29(2):379-403.

GALETTI, M., ALVES-COSTA, C.P., CAZETTA, E. 2003. Effects of forest fragmentation, anthropogenic edges and fruit colour on the consumption of ornithocoric fruits. Biol Cons 111(2): 269-273.

GOODMAN, S.M., GANZHORN, J.U. \& WILME, L. 1997. Observations at a Ficus tree in Malagasy humid forest. Biotropica. 29(4):480-488.

GRAFTON, B.W. \& VANDERHOFF, E.N. Seed dispersal by golden-handed tamarins (Saguinus midas) in Brownsberg Nature Park, Suriname: preliminary results. Neotrop Primates. (No prelo).

ISABIRYE-BASUTA, G.M. \& LWANGA, J.S. 2008. Primate populations and their interactions with changing habitats. Int $\mathrm{J}$ of Primatol. 29(1):35-48.

JANZEN, D.H. 1970. Herbivores and the number of tree species in tropical forests. Amer Nat 104 (940): 501-528.

JULLIOT, C. 1996. Fruit choice by red howler monkeys (Alouatta seniculus) in a tropical rain forest. Am J Primatol. 40(3):261-282.

KISSLING, W.D., RAHBEK, C. \& BOHNING-GAESE, K. 2007. Food plants diversity as broad-scale determinant of avian frugivore richness. Proc $\mathrm{R}$ Soc Lond B. 274(1611):799-808.

KNOGGE, C., HERRERA, T.E.R. \& HEYMANN, E.W. 2003. Effects of passage through tamarin guts on the germination potential of dispersed seeds. Int J Primatol. 24(5):1121-1128.

KORINE, C., KALKO, E.K.V. \& HERRE, E.A. 2000. Fruit characteristics and factors affecting fruit removal in Panamanian community of strangler figs. Oecologia. 123(4):560-568.

KRIJGER, C.L., OPDAM, M., THERY, M. \& BONGERS, F. 1997. Courtship behaviour of manakins and seed bank composition in a French Guianan rain forest. J Trop Ecol. 13(5):631-636.

LAMAN, T.G. 1995. Ficus stupenda germination and seedling establishment in a Bornean rain forest canopy. Ecology. 76(8):2617-2626.

LAMBERT, F.R. \& MARSHALL, A.G. 1991. Keystone sharacteristics of bird dispersed Ficus in a Malaysian lowland rain forest. J Ecol. 79(3):793-809.

LEVEY, D.J. 1987. Seed size and fruit-handling techniques of avian frugivores. Amer Nat. 129(4):471-485.

LOMASCOLO, S.B., SPERANZA, P. \& KIMBALL, R.T. 2008. Correlated evolution of fig size and color supports the dispersal syndromes hypothesis. Oecologia. 156(4):783-796.

MOERMOND, T.C. \& DENSLOW, J.S. 1983. Fruit choice in neotropical birds: effects of fruit type and accessibility on selectivity. J Anim Ecol. 52(2):407-420.

NORCONK, M.A., RAGHANTI, M.A., MARTIN, S.K., GRAFTON, B.W., GREGORY, L.T. \& DIJN, B. 2003. Primates of Brownsberg Natuurpark, Suriname, with particular attention to the Pithecins. Neotrop Primates. 11(2):94-100.

PEJCHAR, L., PRINGLE, R.M., RANGNTHAN, J., ZOOK, J.R., DURAN, G., OVIEDO, F. \& DAILY, G.C. 2008. Birds as agents of seed dispersal 
in a human dominated landscape in southern Costa Rica. Biol Cons. 141(2):536-544.

SCHUPP, E.W. 1993. Quantity, quality and the effectiveness of seed dispersal by animals. Vegetatio. 107/108(1):15-29.

SERIO-SILVA, J.C., RICO-GRAY, V., HERNANDEZ-SALAZAR, L.T. \& ESPINOSA-GOMEZ, R. 2002. The role of Ficus (Moraceae) in the diet and nutrition of a troop of Mexican howler monkeys, Alouatta palliata mexicana, released on an island in southern Veracruz, Mexico. J Trop Ecol. 18(6):913-928.

SHANAHAN, M., SO, S., COMPTON, S.G. \& CORLETT, R. 2001. Figeating by vertebrate frugivores: a global review. Biol Rev Camb Philos Soc. 76(4):529-572.

TELLO, J.G. 2003. Frugivores at a fruiting Ficus in south-eastern Peru. J Trop Ecol. 19(6):717-721.

TERBORGH, J. 1986. Keystone plant resources in the tropical forest. In Conservation biology: the science of scarcity and diversity (M.E. Soule, ED.). Sinauer Associates, Massachusetts, p. 330-344.
WANG, B.C. \& SMITH, T.B. 2002. Closing the seed dispersal loop. Trends Ecol Evo. 17(8):379-385.

WENNY, D.G. \& LEVEY, D.J. 1998. Directed seed dispersal by bellbirds in a tropical cloud forest. Proc Nat Acad Sci USA. 95(11):6204-6207.

WENNY, D.G. 2001. Short-term fruit removal from a neotropical shrub with experimental bicoloured displays. J Trop Ecol. 19(4):469-472.

WESTCOTT, D.A., BENTRUPPERBAUMER, J., BRADFORD, M.G. \& MCKEOWN, A. 2005. Incorporating patterns of dispersal behavior into models of seed dispersal and its effects on estimated dispersal curves. Oecologia. 146(1):57-67.

WHEELWRIGHT, N.T. \& JANSON, C.H. 1985. Colors of bird-dispersed plants in two tropical forests. Amer Nat. 126(6):777-799.

Received 04/03/09

Revised 27/07/09

Accepted 23/09/09 